Article

\title{
Evidence of West Nile Virus (WNV) Circulation in Wild Birds and WNV RNA Negativity in Mosquitoes of the Danube Delta Biosphere Reserve, Romania, 2016
}

\author{
Ana Vasić 1,2, ${ }^{\dagger}$, Luanda Elena Oșlobanu ${ }^{3,+}$, Mihai Marinov ${ }^{4} \mathbb{D}$, Luciana Alexandra Crivei ${ }^{3}$, \\ Ioana Alexandra Rățoi ${ }^{3}$, Adriana Aniță ${ }^{3}$, Dragoș Aniță ${ }^{3}$, Alexandru Doroșencu ${ }^{4}$, \\ Vasile Alexe ${ }^{4}$, Ștefan Răileanu ${ }^{4}$, Predrag Simeunović ${ }^{2}$, Cristian Raileanu ${ }^{1,3}$, \\ Elena Falcuța ${ }^{5}$, Florian Liviu Prioteasa ${ }^{5}\left(\mathbb{D}\right.$, Jovan Bojkovski ${ }^{2}$, Ivan Pavlović ${ }^{6}(\mathbb{D}$, \\ Alexander Mathis ${ }^{7}$, Birke Andrea Tews ${ }^{1}{ }^{1}$, Gheorghe Savuţa ${ }^{3}$, Eva Veronesi ${ }^{7}$, \\ Cornelia Silaghi ${ }^{1,7,8, *}$ and the SCOPES AMSAR training group $\ddagger$ \\ 1 Institute of Infectology, Friedrich-Loeffler-Institut, Südufer 10, 17943 Insel Riems, Germany \\ 2 Faculty of Veterinary Medicine, University of Belgrade, Bul. oslobodjenja 18, 11000 Belgrade, Serbia \\ 3 Faculty of Veterinary Medicine, University of Agricultural Sciences and Veterinary Medicine Iaşi, \\ Aleea Mihail Sadoveanu 3, 700490 Iaşi, Romania \\ 4 Danube Delta National Institute for Research and Development, Strada Babadag 165, 820112 Tulcea, Romania \\ 5 Cantacuzino National Medico-Military Institute for Research and Development, Splaiul Independenţei 103, \\ 05096 Bucharest, Romania \\ 6 Scientific Veterinary Institute of Serbia Belgrade, Vojvode Toze 14, 11000 Belgrade, Serbia \\ 7 National Centre for Vector Entomology, Institute of Parasitology, Vetsuisse Faculty, University of Zürich, \\ Winterthurerstrasse 266a, 8057 Zürich, Switzerland \\ 8 Department of Biology, University of Greifswald, Domstrasse 11, 17489 Greifswald, Germany \\ 9 Faculty for Agriculture, University of Novi Sad, Trg Dositeja Obradovića 8, 21000 Novi Sad, Serbia \\ * Correspondence: cornelia.silaghi@fli.de; Tel.: +0049-3835171172 \\ + Contributed equally. \\ $\ddagger$ SCOPES AMSAR training group: Andrei Cimpan ${ }^{3}$, Lavinia Ciucă ${ }^{3}$, Aleksandar Cojkić ${ }^{2}$, Vladimir \\ Drašković $^{2}$, Miloje Djurić ${ }^{2}$, Uroš Glavinić ${ }^{2}$, Maria Larisa Ivanescu ${ }^{3}$, Mihaela Kavran ${ }^{9}$, Andrei Lupu ${ }^{3}$, \\ Raluca Mindru ${ }^{3}$, Daniela Porea ${ }^{3,4}$, Oliver Radanović ${ }^{9}$, Marko Ristanić ${ }^{2}$, Constantin Roman ${ }^{3}$, Ljubodrag \\ Stanišić $^{2}$, Nemanja Zdravković ${ }^{2}$ and Slavica Vaselek ${ }^{9}$.
}

Received: 8 July 2019; Accepted: 19 August 2019; Published: 21 August 2019

check for updates

\begin{abstract}
West Nile virus (WNV) is a zoonotic flavivirus whose transmission cycle in nature includes wild birds as amplifying hosts and ornithophilic mosquito vectors. Bridge vectors can transmit WNV to mammal species potentially causing West Nile Fever. Wild bird migration is a mode of WNV introduction into new areas. The Danube Delta Biosphere Reserve (DDBR) is a major stopover of wild birds migrating between Europe and Africa. The aim of this study was to investigate the presence of WNV in the DDBR during the 2016 transmission season in wild birds and mosquitoes. Blood from 68 wild birds (nine different species) trapped at four different locations was analyzed by competitive ELISA and Virus Neutralization Test (VNT), revealing positive results in 8/68 (11.8\%) of the wild birds by ELISA of which six samples (three from juvenile birds) were confirmed seropositive by VNT. Mosquitoes ( $n=6523,5$ genera) were trapped with CDC Mini Light traps at two locations and in one location resting mosquitoes were caught. The presence of WNV RNA was tested in 134 pools by reverse transcription quantitative PCR (RT-qPCR). None of the pools was positive for WNV-specific RNA. Based on the obtained results, WNV was circulating in the DDBR during 2016.
\end{abstract}

Keywords: West Nile virus; wild birds; VNT; ELISA; Aedes spp.; Anopheles spp.; Danube Delta 


\section{Introduction}

West Nile virus (WNV) is a zoonotic flavivirus whose transmission cycle in nature includes wild birds as amplifying hosts and ornithophilic mosquito vectors [1]. Bridge vectors (mosquito species feeding on both birds and mammals) can transmit WNV to other species including humans, horses, and other mammals [2]. Certain birds are the primary reservoir hosts for WNV, but there are variations in their susceptibility to infection based on species [3], reservoir competence, and importance as amplifying hosts. After the first detection of WNV lineage 2 in Europe (2004), it was suggested that long distance migratory birds are responsible for the spread of WNV from Africa [4]. The role of resident (sedentary) and short distance migratory birds in the circulation, maintenance, and spread of WNV was also shown [5].

In Romania, the first severe outbreak occurred in 1996 caused by WNV lineage 1 with 393 confirmed human cases [6], while a WNV lineage 2 outbreak occurred in 2010 for the first time [7]. In the Danube Delta Biosphere Reserve (DDBR) WNV was detected in ticks (Hyalomma marginatum marginatum nymph collected in 2013) [8] and mosquitoes (WNV lineage 2 strains in Culex pipiens, Cx. modestus, and Coquillettidia richiardii mosquitoes in 2015, and in 2016 WNV lineage 2 strains belonging to the monophyletic Central/Southern European group of strains which completely replaced the Volgograd 2007-like strain in the mosquito population) [9]. Mosquitoes of the genus Culex are considered to play a major role in the transmission of WNV in Europe [10] but WNV RNA was also detected from pools of Aedes, Anopheles, and Culiseta specimens in previous studies [11,12]. Seroprevalence data for WNV in wild birds in Europe is used for an integrated animal-human-vector approach in WNV surveillance [13]. The aim of this study was to investigate the presence of WNV specific antibodies and RNA in populations of wild birds and mosquitoes, respectively, during the 2016 transmission season in order to assess the circulation of WNV in the DDBR in the frame of a summer training school organized under the capacity-building SCOPES (Scientific cooperation between Eastern Europe and Switzerland) AMSAR project [14].

\section{Materials and Methods}

\subsection{Study Area}

The DDBR (28.18,05,556 longitude East; $45.450,00,000$ latitude North) is a relatively small area (5800 square $\mathrm{km}$ ) at the end of the Danube's $2860 \mathrm{~km}$ long route through Europe towards the Black sea, protected as a whole by Romania and the UNESCO since 1990. It is famous for its diversity and abundance of birds (362 species) [15], and it is one of the major stopover sites for migratory birds on the way to Africa and back to Europe [16].

The Sălcioara area is situated in the southern part of the DDBR, in the middle and western part of the Razim-Sinoe lagoonal system. The Furtuna and Stipoc sites are situated in the middle part of the DDBR, in the center of the fluvial delta. The Caraorman site is located also in the middle part of the DDBR, but in the western part of the marine delta. The Murighiol site is in the western part of the DDBR in the southern part of Murighiol village, being the most anthropic sampling point (Figure 1). 


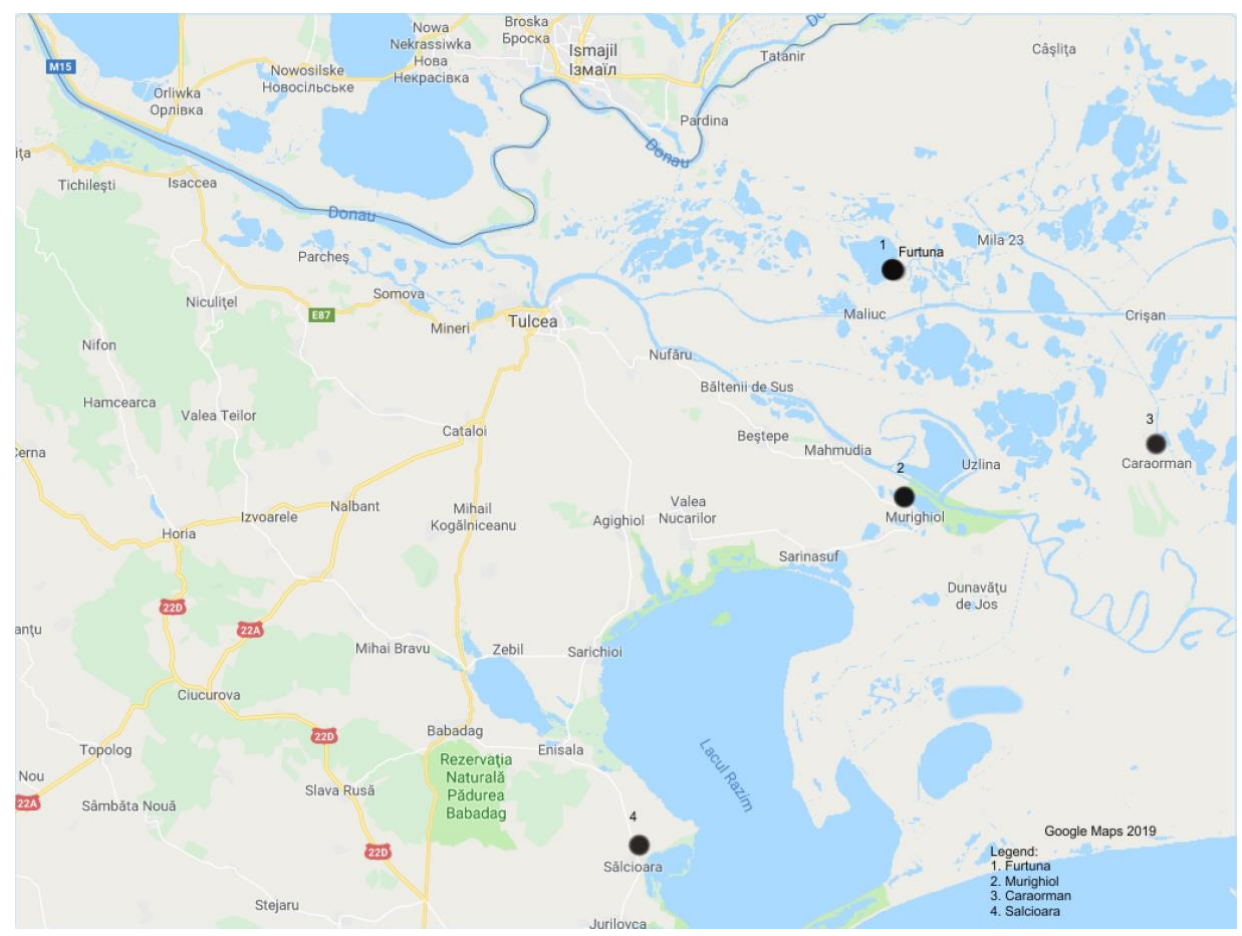

Figure 1. Map of the Danube Delta Biosphere Reserve (DDBR) with sampling locations.

\subsection{Collection and Preparation of Blood Samples from Wild Birds}

Collection of blood samples from wild birds was done during three sampling days in summer (19, 21, 23 July 2016) and a second collection point occurred in November 2016 (17 November) in order to track the WNV seroprevalence at the four different locations in the DDBR. Wild birds were caught by placing the catching mist nets (dimensions: $12 \mathrm{~m}$ long, $2.5 \mathrm{~m}$ high, 5 shelves, $16 \times 16 \mathrm{~mm}$ ) as described in Keyes and Grue, 1982 [17].

Blood was collected from the jugular vein, sera separated and sampled in quantity depending on the size of the bird and stored at $-20{ }^{\circ} \mathrm{C}$ until further use. Age (adult or juvenile) and gender was identified for almost all birds (Table 1). All caught wild birds were in good condition. After taking blood, the birds were measured, banded, and released. The study was approved by the Scientific Council Ethic Commission of the Danube Delta National Institute for Research and Development.

\subsection{Mosquito Collection and Identification}

CDC mini light traps (BioQuip, Rancho Dominguez, CA, USA) with $\mathrm{CO}_{2}$ delivered by dry ice as attractant were used for mosquito trapping during two nights (19 and 21 July 2016) at two locations in the DDBR (Furtuna and Caraorman). The traps were placed $1.5 \mathrm{~m}$ above ground level in the evening and the trapped mosquitoes were collected in the morning the next day. On the third sampling night (22 July 2016) resting mosquitoes were collected by mouth aspirator (John W. Hock Company, Gainesville, FL, USA) at the Stipoc location. Mosquitoes were collected alive at all three locations, immediately frozen in liquid nitrogen, and identified to genus level according to morphological characteristics given by the identification keys in Becker et al., 2010 [18].

\subsection{Serological Examination}

\subsubsection{Competitive ELISA}

A competitive ELISA (ID Screen®West Nile Competition Multi-species, IDVet, Grabels, France) was used according to the manufacturer's instruction to determine the presence of WNV specific antibodies in the collected wild birds' serum samples [19]. 


\subsubsection{Virus Neutralization Test (VNT)}

For confirmation of the positive results obtained by competitive ELISA, a VNT in microtiter format was performed as described in the Manual of Diagnostic Tests and Vaccines for Terrestrial Animals, OIE, 2018 [20]. WNV lineage 1 (Italy, strain 204913/09) was used for the VNT [21]. The results were read after 5 days at $40 \times$ magnification. Presence and absence of cytopathogenic effect (CPE) were evaluated for each sample.

\subsection{Molecular Examination}

\subsubsection{RNA Extraction from Mosquito Pools}

Mosquitoes of the same genus were pooled $(n=134)$ and homogenized using a Tissue Lyser II (Qiagen, Hildesheim, Germany), with shaking twice at 30 1/s for $1 \mathrm{~min}$. RNA extractions were performed with the Qiagen RNeasy Mini Kit (Qiagen, Hilden, Germany) according to the manufacturer's instructions. RNA was eluted in $50 \mu \mathrm{L}$ of elution buffer and was stored at $-80{ }^{\circ} \mathrm{C}$ until further use.

\subsubsection{RT-qPCR for $\mathrm{WNV}$}

In order to determine the presence of WNV specific RNA (target: WNVNS2A) in RNA extracts of mosquito pools, RT-qPCR was performed as described in Eiden et al. 2010 [22].

\section{Results}

Wild Bird Collection and Serological Testing for WNV Antibodies

Altogether 68 wild birds (10 in July and 58 in November 2016) were caught and sampled during this study at four different locations in the Danube Delta Biosphere Reserve (DDBR) (Caraorman $n=3$, Furtuna $n=7$, Murighiol $n=20$, and Sălcioara $n=38$ ). Out of the 68 wild birds, 22 were juveniles (hatched within the 2016 season) and 46 were adults. As for the adult birds: 12 were female and 14 male, with gender un-determined for an additional 20 animals as genders were unable to be distinguished based on plumage at the time of sampling. The species composition included migratory (Acrocephalus scirpaceus/Common Reed-Warbler, $n=3$, Coracias garrulus/blue roller, $n=1$ ), resident (Cyanistes caeruleus/eurasian blue Tit, $n=1$, Parus major/great tit, $n=1$, Passer domesticus/house sparrow, $n=23$, Passer montanus/eurasian tree sparrow, $n=15$, Picus canus/grey-headed woodpecker, $n=2$, Streptopelia decaocto/eurasian collared-dove, $n=1$ ) and partial migrant species (Sturnus vulgaris/common starling, $n=21$ ).

By competitive ELISA, the presence of specific WNV antibodies was shown in 8/68 (11.8\%, CI95 $11.5 \%-12.1 \%$ ) wild birds' serum samples originating from five species. Four positive samples were collected from juvenile birds (three from the Sălcioara location and one from the Furtuna location) and three were collected from adult birds (one at each location Murighiol, Furtuna, and Sălcioara) whilst in one case of an Eurasian Tree Sparrow (from Sălcioara) it was neither possible to distinguish gender nor age (Table 1). In examined locations, the following positivity rates were registered: $2 / 7$ birds $(28.5 \%$, CI95 22.8\%-33.9\%) from Furtuna, 1/20 (5\%, CI95 4.6\%-5.4\%) from Murighiol, and 5/38 (13.2\%, CI95 $12.7 \%-13.7 \%$ ) from Sălcioara. Confirmatory VNTs were performed on 51 samples collected from two locations (Murighiol and Sălcioara) while 17 samples were not available for further testing due to small quantities of sera. In addition, the insufficient amount of sera did not allow us to carry out neutralization tests with other related flaviviruses circulating in Europe. The VNT results for the ELISA positive samples are given in Table 1.

A total of 6523 female mosquitoes were collected from three of the four examined locations (Caraorman, Furtuna, and Stipoc) belonging to five genera (Table 2). The mosquitoes were sorted into 134 pools according to genus, with a maximum of 50 individuals each. No specific WNV RNA was found in any of the tested pools. 
Table 1. Wild birds from Danube Delta Biosphere Reserve that tested positive for West Nile virus (WNV) by competitive ELISA and corresponding Virus Neutralization Test (VNT) results.

\begin{tabular}{|c|c|c|c|c|c|c|}
\hline Species & Age & Gender & Date of Catch & Location & Competitive ELISA Test & VNT Titer \\
\hline Passer montanus/Eurasian Tree Sparrow & NA & Not distinguishable & 21 November 2016 & Sălcioara & Positive & $1: 10$ \\
\hline Passer domesticus/House Sparrow & Adult & $\mathrm{M}$ & 21 November 2016 & Sălcioara & Positive & $1: 40$ \\
\hline Passer domesticus/House Sparrow & Adult & $\mathrm{M}$ & 17 November 2016 & Murighiol & Positive & $1: 10$ \\
\hline Picus canus/Grey-headed Woodpecker & Juvenile & $\mathrm{F}$ & 19 July 2016 & Furtuna & Positive & NA \\
\hline Picus canus/Grey-headed Woodpecker & Adult & $\mathrm{F}$ & 19 July 2016 & Furtuna & Positive & NA \\
\hline Streptopelia decaocto/Eurasian Collared-dove & Juvenile & NA & 21 July 2016 & Sălcioara & Positive & $1: 20$ \\
\hline Sturnus vulgaris/Common Starling & Juvenile & NA & 21 November 2016 & Sălcioara & Positive & $1: 20$ \\
\hline Sturnus vulgaris/Common Starling & Juvenile & NA & 21 November 2016 & Sălcioara & Positive & $1: 80$ \\
\hline
\end{tabular}

NA-not available, M-male, F-female.

Table 2. Mosquito genus composition, number of pools, and individual mosquitoes from three different locations within the DDBR.

\begin{tabular}{|c|c|c|c|c|}
\hline \multirow{3}{*}{ Mosquito Genus } & \multicolumn{3}{|c|}{ Location } & \multirow{3}{*}{$\begin{array}{c}\text { Total } \\
3 \text { Locations } \\
\text { No. Pools (No. Mosquitoes }\end{array}$} \\
\hline & Caraorman & Furtuna & Stipoc & \\
\hline & No. Pools (No. Mosquitoes) & No. Pools (No. Mosquitoes) & No. Pools (No. Mosquitoes) & \\
\hline Aedes & $0(0)$ & $1(38)$ & $0(0)$ & $1(38)$ \\
\hline Anopheles & $27(1348)$ & $65(3181)$ & $5(250)$ & $97(4779)$ \\
\hline Coquilletidia & $7(350)$ & $11(481)$ & $0(0)$ & $18(831)$ \\
\hline Culex & $0(0)$ & $14(675)$ & $0(0)$ & $14(675)$ \\
\hline Culiseta. & $0(0)$ & $4(200)$ & $0(0)$ & $4(200)$ \\
\hline Total: & $34(1698)$ & $95(4575)$ & $5(250)$ & $134(6523)$ \\
\hline
\end{tabular}

Each pool contained up to 50 individual mosquitoes. 


\section{Discussion}

WNV positive wild birds are considered an important environmental predictor of WNV human risk [23]. Resident birds are responsible for local WNV amplification while infected migratory birds disperse WNV over long distances [24]. Hatch-year birds are thought to have a major role in the amplification of WNV in epizootic transmission [25]. The confirmed seropositivity for WNV registered in this study is $8.8 \% \pm 0.07 \%(6 / 68)$ in wild birds' sera samples originating from two out of four examined locations (Murighiol and Sălcioara) in the DDBR which is in concordance with findings in neighboring Serbia ( $8 \%$ seropositivity) [26] and Poland (13.3\% seropositivity) [27]. The majority of seropositive wild bird species in our study belong to the group of resident birds implying an established transmission cycle of WNV in the DDBR. In contrast, in Germany where WNV was not detected until 2018, antibodies were exclusively found in migratory birds, with the exception of one Hooded Crow (Corvus corone cornix) being a short-distance migratory species [28,29]. The geographical distribution of seropositive wild birds of which three were juvenile in two out of four examined locations may indicate the circulation of WNV or other closely related flaviviruses (since the limitations of the performed test exist in relation to cross reactivity) during the 2016 transmission season in the DDBR. In 2016 in the DDBR, 25 out of 227 mosquito pools were tested positive for WNV RNA, all of which were Cx. pipiens pools [9]. In the present study, 134 mosquito pools containing 6523 mosquitoes of five genera were all negative for WNV RNA. In a previous study from Romania from 2011 to 2013, WNV RNA was detected in Cx. pipiens, Cx. modestus, Cq. richiardii, An. hyrcanus, Uranotaenia unguiculata, Ochlerotatus caspius, and An. maculipennis complex [30]. The absence of WNV RNA in the mosquito pools in our study could be due to the short sampling period of three nights in total during July 2016. Even though two ELISA positive grey-headed woodpeckers (Picus canus) were sampled in July, the rest of the seropositive wild birds were caught and sampled during November when the probability of WNV positive findings in both wild birds and mosquitoes is higher because of the longer exposure time during the transmission season.

\section{Conclusions}

During summer and autumn 2016, blood sera from six resident and two migratory wild birds of the DDBR had specific WNV antibodies. Overall, a positivity rate of $8.8 \%$ was found during this study. The detection of WNV specific antibodies from juvenile resident wild birds indicates infection with WNV or other closely related flaviviruses during the 2016 transmission season. Even though the seropositive wild birds were detected at two different locations (Murighiol and Sălcioara), no WNV specific RNA was detected during this study in mosquito pools in the DDBR.

Author Contributions: C.S. designed and coordinated the project; J.B., I.P., G.S., and M.M. coordinated the implementation of the project in Serbia and Romania; E.V., C.S., A.M., E.F., F.L.P., G.S., M.M., D.A., S.R., V.A., A.V., P.S., L.O., and D.A. were trainers in the training schools; A.V., D.A., M.M.,V.A., L.O., E.F., F.L.P., E.V., and C.S. participated in field trapping of wild birds and mosquitoes; M.M., A.D., and V.A. identified the wild bird species; V.A. collected the blood samples from wild birds, A.V., D.A., L.O., P.S., E.V., and C.S. participated in laboratory examinations and mosquito genus identification; L.O., A.L.C., A.A., and I.A.A. performed RNA extractions and real-time PCRs; A.V. and B.A.T. performed VNT. SCOPES AMSAR training group participated in all practical aspects of the study; A.V., L.O., M.M., C.R., and C.S. drafted the manuscript. All authors critically revised the manuscript. All authors approved the final manuscript.

Funding: The project was financed by the SCOPES program of the Swiss National Science Foundation (SNFS) and the Swiss Agency for Development and Cooperation (SDC). We highly acknowledge the Bundesamt für Lebensmittelsicherheit und Veterinärwesen (Switzerland) for funding of the National Centre for Vector Entomology.

Acknowledgments: We kindly thank Davide Lelli, Insituto Zooprofilatico Sperimentale della Lombardia e dell'Emilia Romagna (IZSLER), Italy, for providing WNV lineage 1 strain 203204. Authors thank Kimberly Veenstra (Friedrich-Loeffler-Institut, Greifswald, Germany) for thorough revision of the English language.

Conflicts of Interest: The authors declare no conflict of interest. 


\section{References}

1. Rappole, J.H.; Derrickson, S.R.; Hubalek, Z. Migratory birds and spread of West Nile virus in the Western Hemisphere. Emerg. Infect. Dis. 2000, 6, 319-328. [CrossRef] [PubMed]

2. Veronesi, E.; Paslaru, A.; Silaghi, C.; Tobler, K.; Glavinic, U.; Torgerson, P.; Mathis, A. Experimental evaluation of infection, dissemination, and transmission rates for two West Nile virus strains in European Aedes japonicus under a fluctuating temperature regime. Parasitol. Res. 2018, 117, 1925-1932. [CrossRef] [PubMed]

3. Komar, N.; Langevin, S.; Hinten, S.; Nemeth, N.; Edwards, E.; Hettler, D.; Davis, B.; Bowen, R.; Bunning, M. Experimental infection of North American birds with the New York 1999 strain of West Nile virus. Emerg. Infect. Dis. 2003, 9, 311-322. [CrossRef]

4. Bakonyi, T.; Ivanics, E.; Erdelyi, K.; Ursu, K.; Ferenczi, E.; Weissenbock, H.; Nowotny, N. Lineage 1 and 2 strains of encephalitic West Nile virus, central Europe. Emerg. Infect. Dis. 2006, 12, 618-623. [CrossRef] [PubMed]

5. Valiakos, G.; Touloudi, A.; Athanasiou, L.V.; Giannakopoulos, A.; Iacovakis, C.; Birtsas, P.; Spyrou, V.; Dalabiras, Z.; Petrovska, L.; Billinis, C. Serological and molecular investigation into the role of wild birds in the epidemiology of West Nile virus in Greece. Virol. J. 2012, 9, 266. [CrossRef] [PubMed]

6. Tsai, T.F.; Popovici, F.; Cernescu, C.; Campbell, G.L.; Nedelcu, N.I. West Nile encephalitis epidemic in southeastern Romania. Lancet 1998, 352, 767-771. [CrossRef]

7. Sirbu, A.; Ceianu, C.S.; Panculescu-Gatej, R.I.; Vazquez, A.; Tenorio, A.; Rebreanu, R.; Niedrig, M.; Nicolescu, G.; Pistol, A. Outbreak of West Nile virus infection in humans, Romania, July to October 2010. Eurosurveillance 2011, 16, 19762.

8. Kolodziejek, J.; Marinov, M.; Kiss, B.J.; Alexe, V.; Nowotny, N. The complete sequence of a West Nile virus lineage 2 strain detected in a Hyalomma marginatum marginatum tick collected from a song thrush (Turdus philomelos) in eastern Romania in 2013 revealed closest genetic relationship to strain Volgograd 2007. PLoS ONE 2014, 9, e109905. [CrossRef] [PubMed]

9. Cotar, A.I.; Falcuta, E.; Dinu, S.; Necula, A.; Birlutiu, V.; Ceianu, C.S.; Prioteasa, F.L. West Nile virus lineage 2 in Romania, 2015-2016: Co-circulation and strain replacement. Parasites Vectors 2018, 11, 562. [CrossRef] [PubMed]

10. Balenghien, T.; Vazeille, M.; Grandadam, M.; Schaffner, F.; Zeller, H.; Reiter, P.; Sabatier, P.; Fouque, F.; Bicout, D.J. Vector competence of some French Culex and Aedes mosquitoes for West Nile virus. Vector Borne Zoonotic Dis. 2008, 8, 589-595. [CrossRef] [PubMed]

11. Mancini, G.; Montarsi, F.; Calzolari, M.; Capelli, G.; Dottori, M.; Ravagnan, S.; Lelli, D.; Chiari, M.; Santilli, A.; Quaglia, M.; et al. Mosquito species involved in the circulation of West Nile and Usutu viruses in Italy. Vet. Ital. 2017, 53, 97-110. [CrossRef] [PubMed]

12. Engler, O.; Savini, G.; Papa, A.; Figuerola, J.; Groschup, M.H.; Kampen, H.; Medlock, J.; Vaux, A.; Wilson, A.J.; Werner, D.; et al. European surveillance for West Nile virus in mosquito populations. Int. J. Environ. Res. Public Health 2013, 10, 4869-4895. [CrossRef] [PubMed]

13. Gossner, C.M.; Marrama, L.; Carson, M.; Allerberger, F.; Calistri, P.; Dilaveris, D.; Lecollinet, S.; Morgan, D.; Nowotny, N.; Paty, M.C.; et al. West Nile virus surveillance in Europe: Moving towards an integrated animal-human-vector approach. Eurosurveillance 2017, 22. [CrossRef] [PubMed]

14. Vasic, A.; Zdravkovic, N.; Anita, D.; Bojkovski, J.; Marinov, M.; Mathis, A.; Niculaua, M.; Oslobanu, E.L.; Pavlovic, I.; Petric, D.; et al. Species diversity, host preference and arbovirus detection of Culicoides (Diptera: Ceratopogonidae) in south-eastern Serbia. Parasites Vectors 2019, 12, 61. [CrossRef] [PubMed]

15. Marinov, M.; Pogan, T.; Dorosencu, A.; Nichersu, L.; Alexe, V.; Trifanov, C.; Bozagievici, R.; Tosic, K.; Kiss, B.J. Monitoring the great White Pelican (Pelecanus onocrotalus Linnaeus, 1758) breeding population using drones in 2016 the Danube Delta (Romania). Sci. Ann. Danub. Delta Inst. 2016, 22, 41-52.

16. Danube Delta Biiosphere Reserve Authority. Danube Delta. Available online: http://ddbra.ro/en/danubedelta-biosphere-reserve/danube-delta (accessed on 16 January 2019).

17. Keyes, B.E.; Grue, C.E. Capturing birds with mist nets: A review. North Am. Bird Bander 1982, 7, $2-14$.

18. Becker, N.; Petric, D.; Zgomba, M.; Boase, C.; Madon, M.; Dahl, C.; Kaiser, A. Mosquitoes and Their Control; Springer: Berlin, Germany, 2010. 
19. Ziegler, U.; Angenvoort, J.; Fischer, D.; Fast, C.; Eiden, M.; Rodriguez, A.V.; Revilla-Fernandez, S.; Nowotny, N.; de la Fuente, J.G.; Lierz, M.; et al. Pathogenesis of West Nile virus lineage 1 and 2 in experimentally infected large falcons. Vet. Microbiol. 2013, 161, 263-273. [CrossRef] [PubMed]

20. OIE. Manual of Diagnostic Tests and Vaccines for Terrestrial Animals. In 2.1.24 West Nile Virus; OIE: Paris, France, 2018.

21. Lelli, D.; Moreno, A.; Brocchi, E.; Sozzi, E.; Capucci, L.; Canelli, E.; Barbieri, I.; Zeller, H.; Cordioli, P. West Nile virus: Characterization and diagnostic applications of monoclonal antibodies. Virol. J. 2012, 9, 81. [CrossRef] [PubMed]

22. Eiden, M.; Vina-Rodriguez, A.; Hoffmann, B.; Ziegler, U.; Groschup, M.H. Two new real-time quantitative reverse transcription polymerase chain reaction assays with unique target sites for the specific and sensitive detection of lineages 1 and 2 West Nile virus strains. J. Vet. Diagn. Investig. 2010, 22, 748-753. [CrossRef] [PubMed]

23. Cooke, W.H., 3rd; Grala, K.; Wallis, R.C. Avian GIS models signal human risk for West Nile virus in Mississippi. Int. J. Health Geogr. 2006, 5, 36. [CrossRef] [PubMed]

24. Semenza, J.C.; Tran, A.; Espinosa, L.; Sudre, B.; Domanovic, D.; Paz, S. Climate change projections of West Nile virus infections in Europe: Implications for blood safety practices. Environ. Health 2016, 15, 28. [CrossRef]

25. Hamer, G.L.; Walker, E.D.; Brawn, J.D.; Loss, S.R.; Ruiz, M.O.; Goldberg, T.L.; Schotthoefer, A.M.; Brown, W.M.; Wheeler, E.; Kitron, U.D. Rapid amplification of West Nile virus: The role of hatch-year birds. Vector Borne Zoonotic Dis. 2008, 8, 57-67. [CrossRef]

26. Petrovic, T.; Blazquez, A.B.; Lupulovic, D.; Lazic, G.; Escribano-Romero, E.; Fabijan, D.; Kapetanov, M.; Lazic, S.; Saiz, J. Monitoring West Nile virus (WNV) infection in wild birds in Serbia during 2012: First isolation and characterisation of WNV strains from Serbia. Eurosurveillance 2013, 18. [CrossRef]

27. Niczyporuk, S.J.; Samorek-Salamonowicz, E.; Lecollinet, S.; Pancewicz, S.A.; Kozdrun, W.; Czekaj, H. Occurrence of West Nile Virus antibodies in wild birds, horses, and humans in Poland. BioMed Res. Int. 2014, 2015. [CrossRef]

28. Ziegler, U.; Seidowski, D.; Angenvoort, J.; Eiden, M.; Muller, K.; Nowotny, N.; Groschup, M.H. Monitoring of West Nile virus infections in Germany. Zoonoses Public Health 2012, 59, 95-101. [CrossRef]

29. Michel, F.; Fischer, D.; Eiden, M.; Fast, C.; Reuschel, M.; Muller, K.; Rinder, M.; Urbaniak, S.; Brandes, F.; Schwehn, R.; et al. West Nile Virus and Usutu Virus Monitoring of Wild Birds in Germany. Int. J. Environ. Res. Public Health 2018, 15, 171. [CrossRef]

30. Dinu, S.; Cotar, A.I.; Panculescu-Gatej, I.R.; Falcuta, E.; Prioteasa, F.L.; Sirbu, A.; Oprisan, G.; Badescu, D.; Reiter, P.; Ceianu, C.S. West Nile virus circulation in South-Eastern Romania, 2011 to 2013. Eurosurveillance 2015, 20. [CrossRef]

(C) 2019 by the authors. Licensee MDPI, Basel, Switzerland. This article is an open access article distributed under the terms and conditions of the Creative Commons Attribution (CC BY) license (http://creativecommons.org/licenses/by/4.0/). 